\title{
Expression and localization of mRNAs for matrix metalloproteinases and their inhibitors in mixed bronchioloalveolar carcinomas with invasive components
}

\author{
Naoki Kanomata ${ }^{1,2}$, Rie Nakahara ${ }^{3}$, Tatsuya Oda ${ }^{4}$, Yasuyuki Aoyagi ${ }^{1}$, Genichiro Ishii $^{1}$, \\ Tomoyuki Yokose ${ }^{1}$, Takahiro Hasebe ${ }^{1}$, Kanji Nagai ${ }^{3}$, Hiroshi Yokozaki ${ }^{2}$ and Atsushi Ochiai ${ }^{1}$ \\ ${ }^{1}$ Pathology Division, National Cancer Center Research Institute East, Chiba, Japan; ${ }^{2}$ Surgical Pathology \\ Division, Kobe University Hospital, Kobe, Japan; ${ }^{3}$ Divisions of Thoracic Oncology, National Cancer Center \\ Hospital East, Chiba, Japan and ${ }^{4}$ Hepatobiliary and Pancreatic Surgery, National Cancer Center Hospital \\ East, Chiba, Japan
}

\begin{abstract}
Matrix metalloproteinases (MMPs) are believed to play an essential role in cancer invasion, although detailed differences between noninvasive and invasive lung carcinomas are still unclear. To elucidate the expression and activity patterns of MMPs in noninvasive and invasive carcinoma of the lung, we performed in situ hybridization and real-time reverse transcription-polymerase chain reaction to detect messenger RNAs (mRNAs) of MMPs and their tissue inhibitors (TIMPs). The basement membrane was evaluated by immunohistochemistry for type IV collagen. Gelatinase activity was examined by zymography and in situ zymography. A total of 14 surgically resected primary pulmonary adenocarcinomas were used for this study. All the tumors were adenocarcinoma mixed bronchioloalveolar carcinomas according to the 1999 WHO classification. MMP and TIMP2 mRNAs were detected by in situ hybridization in all samples, in both noninvasive and invasive carcinoma components. Signals for MMP mRNAs were significantly higher in both noninvasive and invasive carcinomas than in tumor-free lung tissue. However, the differences were small between noninvasive and invasive carcinomas, not only in the amount of mRNA but also in the activity of the MMPs. In most carcinomas, stromal fibroblast-type cells tended to express levels of MMP and TIMP2 mRNAs that were higher than or at least similar to those expressed in epithelial cells. Our data on mixed adenocarcinoma suggest that noninvasive carcinoma areas already express a molecular mechanism involving MMPs similar to that expressed by invasive carcinoma areas. Stromal fibroblast-type cells seem to be the most important source of MMPs, from the earliest event of tumor invasion by pulmonary adenocarcinomas.

Modern Pathology (2005) 18, 828-837, advance online publication, 14 January 2005; doi:10.1038/modpathol.3800365
\end{abstract}

Keywords: bronchioloalveolar carcinoma; in situ hybridization; matrix metalloproteinase

Matrix metalloproteinase (MMP) is essential in remodeling the extracellular matrix. The degradation of the extracellular matrix and basement membranes by MMPs is believed to be crucial in tumor invasion. ${ }^{1,2}$ Tissue inhibitor of metalloproteinases (TIMPs) were initially recognized as inhibitors of MMPs, as the name implies. However, subsequent studies revealed that TIMP2 also plays an important role in the activation of MMP2. A complex of TIMP2

Correspondence: Dr A Ochiai, MD, Pathology Division, National Cancer Center Research Institute East, 6-5-1, Kashiwanoha, Kashiwa, Chiba 277-8577, Japan.

E-mail: aochiai@east.ncc.go.jp

Received 1 September 2004; revised 29 October 2004; accepted 10 November 2004; published online 14 January 2005 and MT1-MMP is now known to be a receptor and activator of MMP2. ${ }^{3}$

MMP1, MMP2, MMP3, MMP7, MMP9, MMP11, MMP13, MT1-MMP, TIMP1, and TIMP2 have been detected in various histological types of lung carcinomas. $^{4-18}$ However, previous studies rarely examined noninvasive carcinomas, and little is known about how MMP expression differs in noninvasive and invasive carcinomas. Immunohistochemical detection of MMP2 in bronchioloalveolar carcinomas has produced a great variety of results. The expression frequency of MMP2 in bronchioloalveolar carcinomas has been reported to range from 17 to $96 \% .{ }^{19-21}$ This might be due to the different immunodetection methods used. Another possible reason for this diversity is the 
leaching of target proteins that can occur during fixation, processing, or staining. MMPs other than membrane-type MMPs are secreted proteins. Therefore, in situ hybridization has the advantage over immunohistochemistry in allowing detection of the actual pattern of MMP synthesis. Using in situ hybridization, we excluded reactive changes such as desquamative interstitial pneumonia-like reaction from the evaluation of messenger RNAs (mRNAs) for MMPs. Morphological studies that pinpoint the distribution and degree of synthesis of MMP transcripts are few, and as far as we know, this kind of study has not been attempted on preinvasive lung lesions. In this study, we investigated the mRNAs for MMP2, MMP9, MT1-MMP, and TIMP2 in mixed type pulmonary adenocarcinomas with noninvasive (bronchioloalveolar) and invasive areas using nonradioactive in situ hybridization. The basement membrane was evaluated by immunohistochemical detection of type IV collagen. Real-time reverse transcription-polymerase chain reaction (RT-PCR) for MMP and TIMP mRNAs and conventional and in situ zymography were also used.

\section{Materials and methods}

\section{Tissue Samples}

A total of 14 pulmonary adenocarcinomas were analyzed (Table 1). All the tumors were classified as mixed bronchioloalveolar carcinoma according to the 1999 World Health Organization classification. ${ }^{22}$ The tumors were collected by lobectomy at the National Cancer Center Hospital East (Kashiwa, Japan) between July 2000 and February 2001. The TNM classification was used for clinical staging. ${ }^{23}$ Fresh tumor tissue and tumor-free tissue from each patient was quickly frozen in liquid nitrogen and stored at $-80^{\circ} \mathrm{C}$ until the extraction of RNA and protein. Tissue samples from the tumor-free areas of the lungs, the noninvasive component, and the invasive carcinoma component were frozen in liquid nitrogen with OCT compound (Miles, Inc., Elkhart, IN, USA) and stored at $-80^{\circ} \mathrm{C}$ for in situ hybridization, immunohistochemistry, and in situ zymography.

\section{Immunohistochemistry of Type IV Collagen}

Acetone-fixed cryostat sections were used for immunohistochemical staining. The sections were treated with $0.3 \% \mathrm{H}_{2} \mathrm{O}_{2}$ in methanol for $15 \mathrm{~min}$ at room temperature to block endogenous peroxidase activity. They were then washed with phosphatebuffered saline (PBS). The tissues were then incubated with monoclonal antibody directed against type IV collagen (1:50; clone CIV 22, Dako, Glostrup, Denmark) for $1 \mathrm{~h}$ at room temperature. The samples were washed with Tris-buffered saline and the color was developed using the EnVision + System (Dako), according to the manufacturer's instructions. The chromogen was diaminobenzidine. Sections were counterstained with hematoxylin and mounted. A sample from which the primary antibody was omitted acted as the negative control. The degree of basement membrane preservation was scored as complete preservation (CP), partial destruction (PD), or complete destruction (CD), as described previously. ${ }^{24}$

\section{RNA Extraction and Reverse Transcription}

Total RNA was extracted used by Trizol reagent (Life Technologies, Inc., Rockville, MD, USA). To avoid the contamination of DNA, the samples were treated with $40 \mathrm{U}$ of RNase-free DNase I (Takara, Kusatsu, Japan) in $200 \mu$ l volume of RNA solution with DEPC$\mathrm{H}_{2} \mathrm{O}, 10 \mathrm{mM}$ of $\mathrm{MgCl}_{2}$, and $40 \mathrm{U}$ of RNase Inhibitor (Toyobo, Osaka, Japan) at room temperature for $15 \mathrm{~min}$. The RNA samples were quantified by spectrophotometry. Complementary DNA (cDNA)

Table 1 Clinicopathological features

\begin{tabular}{|c|c|c|c|c|c|c|c|}
\hline Patient & Age (years)/sex & Location & Size $(\mathrm{cm})$ & Stage (TNM) & Subtype & Growth pattern & Extent of lepidic growth (\%) \\
\hline 1 & $73 / \mathrm{M}$ & LLL & 16 & 1B (200) & M & BAC, P & 80 \\
\hline 2 & $74 / \mathrm{M}$ & RUL & 4 & 1B (200) & NM & BAC, P & 90 \\
\hline 3 & $71 / \mathrm{F}$ & LLL & 4 & $1 \mathrm{~B}(200)$ & NM & BAC, $\mathrm{P}$ & 95 \\
\hline 4 & $68 / \mathrm{F}$ & RUL & 2.7 & $2 \mathrm{~A}(110)$ & NM & BAC, $\mathrm{P}$ & 80 \\
\hline 5 & $66 / \mathrm{M}$ & RUL & 4.3 & $1 \mathrm{~B}(200)$ & NM & BAC, $P$ & 80 \\
\hline 6 & $82 / \mathrm{M}$ & RUL & 5.1 & $1 B(200)$ & NM & BAC, P & 90 \\
\hline 7 & 73/M & LLL & 15.2 & 2B (210) & NM & BAC, P & 30 \\
\hline 8 & $78 / \mathrm{F}$ & RUL & 2.6 & $1 \mathrm{~A}(100)$ & NM & BAC, $\mathrm{P}$ & 40 \\
\hline 9 & $65 / \mathrm{M}$ & RLL & 3 & $1 \mathrm{~A}(100)$ & NM & BAC, P & 40 \\
\hline 10 & $62 / \mathrm{M}$ & RML & 3.8 & $2 \mathrm{~B}(210)$ & NM & $\mathrm{BAC}, \mathrm{P}$ & 30 \\
\hline 11 & $68 / \mathrm{F}$ & RUL & 2.8 & 1B (200) & NM & BAC, P & 90 \\
\hline 12 & $75 / \mathrm{M}$ & RUL & 4.5 & 1B (200) & NM & BAC, P & 40 \\
\hline 13 & $65 / F$ & RUL & 3.2 & $1 \mathrm{~B}(200)$ & NM & $\mathrm{BAC}, \mathrm{A}$ & 80 \\
\hline 14 & $64 / \mathrm{F}$ & RUL & 2.9 & $1 B(200)$ & NM & $\mathrm{BAC}, \mathrm{P}$ & 80 \\
\hline
\end{tabular}

RUL, right upper lobe; RML, right middle lobe; RLL, right lower lobe; LUL, left upper lobe; LLL, left lower lobe; M, mucinous type; NM, nonmucinous type; BAC, bronchioloalveolar pattern; P, papillary pattern; A, acinar pattern. 
were synthesized with oligo $(\mathrm{dT})_{20}$ primer using the ThermoScript RT-PCR System (Life Technologies) according to the manufacturer's protocol. The cDNA products were purified using the QIAquick PCR Purification Kit (Qiagen, Hilden, Germany) and eluted in $10 \mathrm{mM}$ of Tris-HCl pH 8.5.

\section{Quantitative Real-Time PCR}

Quantitative real-time fluorescence PCR was performed using a LightCycler instrument (Roche Diagnostics GmbH, Mannheim, Germany) and SYBR Green as the fluorogenic dye. cDNA solution $(1 \mu \mathrm{l})$ corresponding to $100 \mathrm{ng}$ of total RNA was subjected to 40 PCR cycles $\left(10 \mathrm{~s}\right.$ at $95^{\circ} \mathrm{C}, 10 \mathrm{~s}$ at $60-68^{\circ} \mathrm{C}$, and $10-15 \mathrm{~s}$ at $72^{\circ} \mathrm{C}$ ) in $10 \mu \mathrm{l}$ reaction mixture containing $1 \times$ LightCycler-DNA Master SYBR Green I (Roche), 2.25-4.0 $\mathrm{mM} \mathrm{MgCl}_{2}$, and $0.25 \mu \mathrm{M}$ each gene-specific primer: 5'-TCTCCTGACATTGACCTTGGC-3' (MMP2 forward) and 5'-CAAGGTGCTGGCTGAGTAGATC-3' (MMP2 reverse); 5'-CCCTTCCTTATCGCCGACAA G-3' (MMP9 forward) and 5'-AACATCCGGTCCACCT CGC-3' (MMP9 reverse); 5'-TCCAGCAACTTTATGGG GGTG-3' (MT1-MMP forward) and 5'-AGGTTCCAGG GACGCCTCA-3' (MT1-MMP reverse); 5'-CTTCCACA GGTCCCACAACC-3' (TIMP1 forward) and 5'-CAGC CCTGGCTCCCGAGGC-3' (TIMP1 reverse); or 5'-CTG GACGTTGGAGGAAAAGAAG-3' (TIMP2 forward) and $5^{\prime}$-TGCTTATGGGTCCTCGATGTC-3' (TIMP2 reverse). After amplification, a melting curve was obtained by cooling the product to $60^{\circ} \mathrm{C}$, and heating to $94^{\circ} \mathrm{C}$ at $0.2^{\circ} \mathrm{C} / \mathrm{s}$ with fluorescence collection at $0.2^{\circ} \mathrm{C}$ intervals. To confirm the amplification specificity, the PCR products were subjected to meltingcurve analysis and subsequent agarose gel electrophoresis. The PCR products of each reaction were used as external PCR standards. The serial $10^{2}$-fold dilutions of these PCR products, corresponding to $1 \times 10^{8}-1 \times 10^{2}$ copies $/ \mu \mathrm{l}$, were amplified in parallel with the experimental samples, as described above. Based on the amplification curves of the external standards, a standard curve was generated for each cDNA. LightCycler software was used to calculate approximate gene-specific mRNA copy numbers.

\section{Preparation of Digoxigenin-Labeled cRNA Probes}

The cDNAs were subcloned into the BlueScript transcription vector and the constructs were linearized with the appropriate restriction enzymes to allow transcription of both antisense and sense RNA probes. The probe sizes for MMP2, MMP9, MT1MMP, and TIMP2 were 416 base pairs (bp; nucleotides 1264-1680), 454 bp (nucleotides 1554-2008), $356 \mathrm{bp}$ (nucleotides 948-1303), and $362 \mathrm{bp}$ (nucleotides 574-936), respectively. The transcription products were designed to eliminate the risk of crosshybridization to other MMPs. Digoxigeninlabeled single-stranded RNA probes were generated with the DIG RNA Labeling Kit (Roche).

\section{In Situ Hybridization}

Frozen tissue sections ( $8 \mu \mathrm{m}$ thick) were fixed in $4 \%$ paraformaldehyde-PBS for $20 \mathrm{~min}$ and rinsed in DEPC- $\mathrm{H}_{2} \mathrm{O}$. The sections were treated with $1 \mu \mathrm{g} / \mathrm{ml}$ proteinase $\mathrm{K}$ (Dako) at room temperature for $5 \mathrm{~min}$, and the background was quenched with $0.3 \% \mathrm{H}_{2} \mathrm{O}_{2}$ in methanol for $20 \mathrm{~min}$. Hybridization was performed at $50^{\circ} \mathrm{C}$ overnight with RNA probes at a concentration of $0.5 \mu \mathrm{g} / \mathrm{ml}$ in mRNA In Situ Hybridization Solution (Dako).

Stringent posthybridization washes were for $20 \mathrm{~min}$ at $55^{\circ} \mathrm{C}$ in $0.1 \times \mathrm{SSC}$, then in $0.01 \times$ SSC. The samples were then washed in Tris-buffered saline, and the slides incubated with anti-digoxigenin-HRP antibody (1:400; Dako) for $60 \mathrm{~min}$ at room temperature. To amplify the signal, biotinyl-tyramide solution (GenPoint, Dako) was added to the slides, which were then incubated for $15 \mathrm{~min}$. After the slides were washed, they were incubated with streptavidin-HRP (Dako) for $15 \mathrm{~min}$. The signals were visualized with diaminobenzidine for $2-5 \mathrm{~min}$. Sections were counterstained with hematoxylin. Sense RNA probes were used as the negative control for each hybridization reaction, and samples with no RNA probe also acted as negative controls for each run. The results were reported as follows:,$-<10 \%$ reactivity;,$+ 10-40 \%$;,$++ 40-70 \% ;+++, 70-$ $100 \%$. Alternatively, the results of in situ hybridization were scored for the statistical analysis: $0,<10 \%$ reactivity; $1,10-40 \% ; 2,40-70 \% ; 3,70-100 \%$.

\section{Tissue Homogenates and Gelatin Zymography}

Tissue samples from pulmonary adenocarcinomas and tumor-free tissues stored at $-80^{\circ} \mathrm{C}$ were homogenized on ice in $50 \mathrm{mM}$ Tris-HCl buffer ( $\mathrm{pH} 7.5)$. containing $0.15 \mathrm{M} \mathrm{NaCl}, 10 \mathrm{mM} \mathrm{CaCl}_{2}, 0.02 \% \mathrm{NaN}_{3}$, and $0.05 \%$ Brij 35 . The homogenates were then centrifuged at $10000 \mathrm{~g}$ for $20 \mathrm{~min}$ at $4^{\circ} \mathrm{C}$. After protein concentrations were measured, the supernatants $(50 \mu \mathrm{g}$ of protein/lane) were incubated at $37^{\circ} \mathrm{C}$ for $30 \mathrm{~min}$ in sodium dodecyl sulfate (SDS) sample buffer without reducing agent, then resolved by SDS-polyacrylamide gel electrophoresis on $10 \%$ polyacrylamide gels containing $0.1 \%$ gelatin at $4{ }^{\circ} \mathrm{C}$. After electrophoresis, the gels were washed in $2.5 \%$ Triton X-100 to remove the SDS, incubated for $24 \mathrm{~h}$ at $37^{\circ} \mathrm{C}$ in $50 \mathrm{mM}$ Tris- $\mathrm{HCl}(\mathrm{pH} 7.5)$ containing $0.15 \mathrm{M} \mathrm{NaCl}, 10 \mathrm{mM} \mathrm{CaCl}_{2}$, and $0.02 \% \mathrm{NaN}_{3}$, and then stained with $0.1 \%$ Coomassie brilliant blue R250. The ratio of activated MMP2 to total MMP2 activity $(62 \mathrm{kDa} /[66 \mathrm{kDa}+62 \mathrm{kDa}])$ was calculated from the gelatinolytic activity measured by densitometric analysis of the gel. ${ }^{8}$

\section{Film In Situ Zymography}

In situ zymography was performed essentially as described previously. ${ }^{25}$ Briefly, frozen sections cut 
with a cryostat were mounted onto gelatin films that were coated with $7 \%$ gelatin solution (Fuji Photo Film Co., Ltd, Tokyo, Japan). The films with sections were incubated for $4 \mathrm{~h}$ at $37^{\circ} \mathrm{C}$ in a moist chamber, stained with $0.3 \%$ Biebrich Scarlet (Aldrich Chemical Co., Inc., Milwaukee, WI, USA), and counterstained with hematoxylin. To confirm the specificity of in situ zymography, frozen sections were also placed onto gelatin-coated film containing 1,10phenanthroline (Fuji Photo Film), which is an inhibiter of MMPs. The results are reported as follows: - , negative; \pm , mild reaction; + , extensive reaction.

\section{Statistical Analysis}

Statistical analysis was performed with StatView version 5.0 (SAS Institute Inc., Cary, NC, USA). Differences were analyzed using the Mann-Whitney $U$-test and the Scheffé method. A value of $P<0.05$ was deemed statistically significant.

\section{Results}

\section{Clinicopathological Features}

Clinical and pathological data for the 14 patients in the study are summarized in Table 1 . They consisted of eight men and six women, with a mean age of 70 years (range, 62-82 years). All were Japanese. Histologically, all the tumors were adenocarcinoma mixed bronchioloalveolar carcinomas. All noninvasive carcinomas were bronchioloalveolar carcinomas. All but one invasive carcinomas were papillary carcinomas; the other invasive carcinoma was an acinar carcinoma. The proportion of the carcinoma that was bronchioloalveolar ranged from 30 to $95 \%$. In the noninvasive carcinoma area, 13 carcinomas were nonmucinous and one was mucinous. Two carcinomas were stage $1 \mathrm{~A}$, nine were stage $1 \mathrm{~B}$, one was stage $2 \mathrm{~A}$, and two were stage $2 \mathrm{~B}$.

\section{Type IV Collagen Immunohistochemistry}

The basement membrane was partially destroyed in four of 14 lesions among the noninvasive carcinomas (Table 3, Figure 1). All four lesions had stromal fibroblast proliferation. We confirmed the complete preservation of the basement membrane in tumorfree tissues and its complete destruction in invasive carcinoma tissues.

\section{Quantitative Real-Time RT-PCR}

PCR results were positive for MMP2, MMP9, TIMP1, and TIMP2 in all tumor-free and carcinoma tissues (Table 2). Eight of 14 tumor-free samples (57\%) and 12 of 14 carcinoma samples (86\%) expressed MT1MMP mRNA, as detected by PCR. TIMP expression

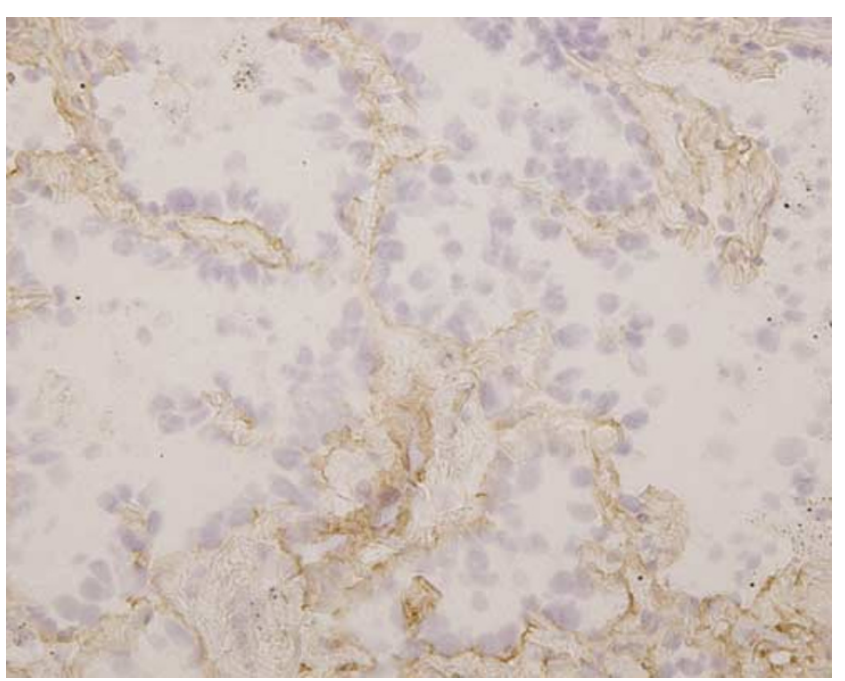

Figure 1 Type IV collagen immunohistochemistry showing partial destruction of the basement membrane in a bronchioloalveolar carcinoma with fibrotic focus.

Table 2 Results of quantitative real-time RT-PCR

\begin{tabular}{lccl}
\hline & Tumor-free tissue & Tumor tissue & P-value \\
\hline MMP2 & $96.65 \pm 120.35$ & $282.57 \pm 603.85$ & 0.2689 \\
MMP9 & $15.71 \pm 17.18$ & $179.44 \pm 399.73$ & 0.1378 \\
MT1MMP & $21.81 \pm 29.23$ & $101.57 \pm 211.59$ & 0.1741 \\
TIMP1 & $1739.54 \pm 2273.48$ & $3191.88 \pm 3821.46$ & 0.2326 \\
TIMP2 & $10331.61 \pm 13206.87$ & $4483.62 \pm 5172.19$ & 0.135 \\
\hline
\end{tabular}

Copy numbers/100 ng total RNA, mean \pm s.d.

was very much higher than MMP expression in both tumor-free and carcinoma samples. MMP2 and MMP9 mRNA levels tended to be higher in carcinoma tissue than in tumor-free tissue, whereas TIMP2 expression tended to be higher in tumor-free tissue than in carcinoma tissue.

\section{In Situ Hybridization}

Hybridization with antisense probes for MMP2, MMP9, MT1-MMP, and TIMP2 yielded dot-like signals in the cytoplasm, whereas hybridization with sense probes produced negative results. Samples containing no RNA probe also produced negative results. The results of in situ hybridization are summarized in Table 3. Tumor-free alveolar epithelial and/or subepithelial fibroblast-type cells displayed MMP2, MMP9, and MT1-MMP expression in 13 of 14 patients (93\%), whereas TIMP2 expression was detected in 10 of 14 patients $(71 \%)$. In all patients, lesions of both the bronchioloalveolar carcinoma component and the invasive carcinoma component expressed transcripts for MMP2, MMP9, MT1-MMP, and TIMP2 in epithelial and/or fibroblast-type cells (Figure 2a-h). Alveolar macrophages, neutrophils, lymphocytes, and endothelial 
Table 3 Results of in situ hybridization and type IV collagen immunohistochemistry in 14 cases of pulmonary adenocarcinoma

\begin{tabular}{|c|c|c|c|c|c|c|c|c|c|c|c|c|c|c|c|}
\hline \multirow[t]{2}{*}{ Patients } & \multicolumn{3}{|c|}{ Type IV collagen } & \multicolumn{3}{|c|}{$M M P 2(E / S)$} & \multicolumn{3}{|c|}{$M M P 9(E / S)$} & \multicolumn{3}{|c|}{$M T 1-M M P(E / S)$} & \multicolumn{3}{|c|}{ TIMP2 (E/S) } \\
\hline & $N$ & NIN & $I N V$ & $N$ & $N I N$ & $I N V$ & $N$ & NIN & $I N V$ & $N$ & NIN & $I N V$ & $N$ & NIN & $I N V$ \\
\hline 1 & CP & CP & CD & $+/+$ & $+/++$ & $+/++$ & $+/+$ & $++/+$ & $++/++$ & $+1+$ & $++/+$ & $++/+++$ & $-1+$ & $+/+$ & $+/++$ \\
\hline 2 & CP & CP & CD & $-1-$ & $+/++$ & $+/++$ & $+/+$ & $++/++$ & $++/++$ & $+/+$ & $+++/+++$ & $+++/++$ & $-1-$ & $-1+$ & $-1+$ \\
\hline 3 & $\mathrm{CP}$ & $\mathrm{CP}$ & $\mathrm{CD}$ & $+/+$ & $+/++$ & $+/++$ & $-1-$ & $-1+$ & $+/++$ & $+/++$ & $++/+++$ & $+++/+++$ & $-1-$ & $-1+$ & $+/+$ \\
\hline 4 & CP & PD & CD & $+/+$ & $+/++$ & $+/+++$ & $+/++$ & $+/++$ & $++/++$ & $+/++$ & +/++ & $+/++$ & $-1+$ & $-1+$ & $-/++$ \\
\hline 5 & CP & $\mathrm{CP}$ & CD & $-/++$ & $+/++$ & $+/+++$ & +/+ & +/+ & +/++ & $+/+$ & $++/+$ & $+++/+$ & $-1+$ & $+/+$ & $+/++$ \\
\hline 6 & CP & CP & $\mathrm{CD}$ & $-1+$ & $-/++$ & $+/++$ & $-1-$ & $+/++$ & $+/++$ & $++/+++$ & $++/+++$ & $++/+++$ & $-1+$ & $+/+$ & $+/++$ \\
\hline 7 & CP & CP & CD & $-1+$ & $+/++$ & $+/++$ & $+/+$ & $++/+$ & $+/+++$ & $+/+$ & $++/++$ & $++/++$ & $+/+$ & $+/+$ & $+/++$ \\
\hline 8 & $\mathrm{CP}$ & CP & CD & $-1+$ & $-/+$ & $+/+++$ & $-1+$ & $++/++$ & $++/+$ & $-1+$ & $++/++$ & $+++/+++$ & $-1-$ & $+/+$ & $+/+$ \\
\hline 9 & CP & PD & CD & $+/++$ & $+/++$ & $+/++$ & $+/+$ & $++/+++$ & $+++/+++$ & $-/+$ & $++/++$ & $++/+++$ & $+/+$ & $+/+$ & $+/++$ \\
\hline 10 & $\mathrm{CP}$ & $\mathrm{CP}$ & $\mathrm{CD}$ & $+/+$ & $+/++$ & $++/+++$ & $++/++$ & $++/++$ & $++/++$ & $++/+++$ & $+++/+++$ & $++/+++$ & $+/++$ & $+/++$ & $+/++$ \\
\hline 11 & $\mathrm{CP}$ & $\mathrm{CP}$ & CD & $+/++$ & $++/++$ & $++/+++$ & $+/++$ & $++/++$ & $++/++$ & $++/++$ & $++/+$ & $++/+$ & $-/+$ & $+/+$ & $+/+$ \\
\hline 12 & CP & CP & CD & $++/++$ & $++/++$ & $++/+++$ & $++/+$ & $++/++$ & $++/++$ & $-1-$ & $++/+$ & $+++/++$ & $-1+$ & $+/+$ & $++/+$ \\
\hline 13 & $\mathrm{CP}$ & PD & $\mathrm{CD}$ & $+/+++$ & $++/+++$ & $++/+++$ & $+/+$ & $++/++$ & $++/+++$ & $+++/++$ & $+++/+++$ & $+++/+++$ & $-1-$ & $+/-$ & $+/+$ \\
\hline 14 & $\mathrm{CP}$ & $\mathrm{PD}$ & CD & $+/++$ & $++/+++$ & $++/++$ & $+/+$ & $+++/+++$ & $+++/++$ & $+/+$ & $++/++$ & $++/++$ & $+/+$ & $++/++$ & $-/+$ \\
\hline
\end{tabular}

E, epithelial cells; S, stromal fibroblast-type cells; N, tumor-free tissue; NIN, noninvasive carcinoma area; INV, invasive carcinoma area; CP, complete preservation; $\mathrm{PD}$, partial destruction; $\mathrm{CD}$, complete destruction.

cells showed signals of various strengths for MMPs and TIMP2.

Expression of all the MMP and TIMP2 mRNAs examined was higher in noninvasive and invasive carcinomas than in tumor-free tissue. Levels of mRNA expression did not differ significantly between noninvasive and invasive carcinomas (Table 4).

A comparative analysis of mRNA expression in epithelial cells and stromal fibroblast-type cells is shown in Table 5. Stromal fibroblast-type cells expressed significantly higher levels of MMP2 mRNA than did epithelial cells in both noninvasive and invasive components $(P=0.0003$ and $P<0.0001$, respectively). In the invasive carcinoma component, stromal fibroblast-type cells also expressed higher levels of TIMP2 mRNA than did epithelial cells $(P=0.0245)$. Levels of MMP9 mRNA and MT1-MMP mRNA were almost the same in both noninvasive and invasive carcinomas.

\section{Correlation between Basement Membrane Status and In Situ Hybridization Results in Noninvasive Carcinoma Area}

In noninvasive carcinoma areas, the correlation between the degree of basement membrane preservation and in situ hybridization results was analyzed statistically (Table 6). The stromal fibroblast-type cells had significantly higher levels of MMP2 and MMP9 mRNAs in the specimens with partially destroyed basement membrane than were observed in the specimens with completely pre- served basement membranes $(P=0.0301$ for MMP2 and $P=0.0260$ for MMP9).

\section{Zymography and Film In Situ Zymography}

Using gelatin zymography, gelatinolytic activities of approximately 92,66 , and $62 \mathrm{kDa}$ were detected in all the tumor-free (14/14 patients) and carcinoma tissues examined (14/14 lesions). These corresponded to the latent form of MMP9, and the latent and active forms of MMP2, respectively. The MMP2 activity detected by zymography was measured by evaluating the gels densitometrically, and the ratio between activated and total MMP2 $(62 \mathrm{kDa} /[66+$ $62 \mathrm{kDa}$ ]) was calculated. The activation ratio for MMP2 was significantly higher in tumor tissue $(54.1 \pm 14.7)$ than in tumor-free tissue $(33.3 \pm 10.0$; $P<0.01)$ (Table 7$)$. The tumor/nontumor $(\mathrm{T} / \mathrm{N})$ ratio for MMP2 activation ranged from 0.83 to 2.57 (mean, 1.71). The $\mathrm{T} / \mathrm{N}$ ratios for tumors with lymph node metastasis $(1.97 \pm 0.67)$ tended to be higher than those for tumors without lymph node metastasis $(1.64 \pm 0.47)$.

The gelatinolytic activity assessed by film in situ zymography was minimal to mild in tumor-free tissue, whereas gelatinolytic activity was clearly evident in noninvasive carcinoma and invasive carcinoma areas (Figure 3a). Extensive gelatinolytic activity was observed in 12 of 14 noninvasive carcinoma areas $(86 \%)$, whereas the remaining two cases showed mild reactivity. In all cases, invasive carcinomas displayed extensive gelatinolytic activity (Table 7).

Figure 2 Frozen sections. In situ hybridization for mRNAs in noninvasive carcinomas (a, $\mathbf{c}, \mathbf{e}, \mathbf{g})$ and invasive carcinomas $(\mathbf{b}, \mathbf{d}, \mathbf{f}, \mathbf{h})$ mRNAs for MMP2 (a, b) and TIMP2 (g, h) were predominantly expressed in stromal fibroblast-type cells. mRNAs for MMP9 (c, d) and MT1-MMP (e, f) were expressed equally carcinoma cells and stromal fibroblast-type cells. 

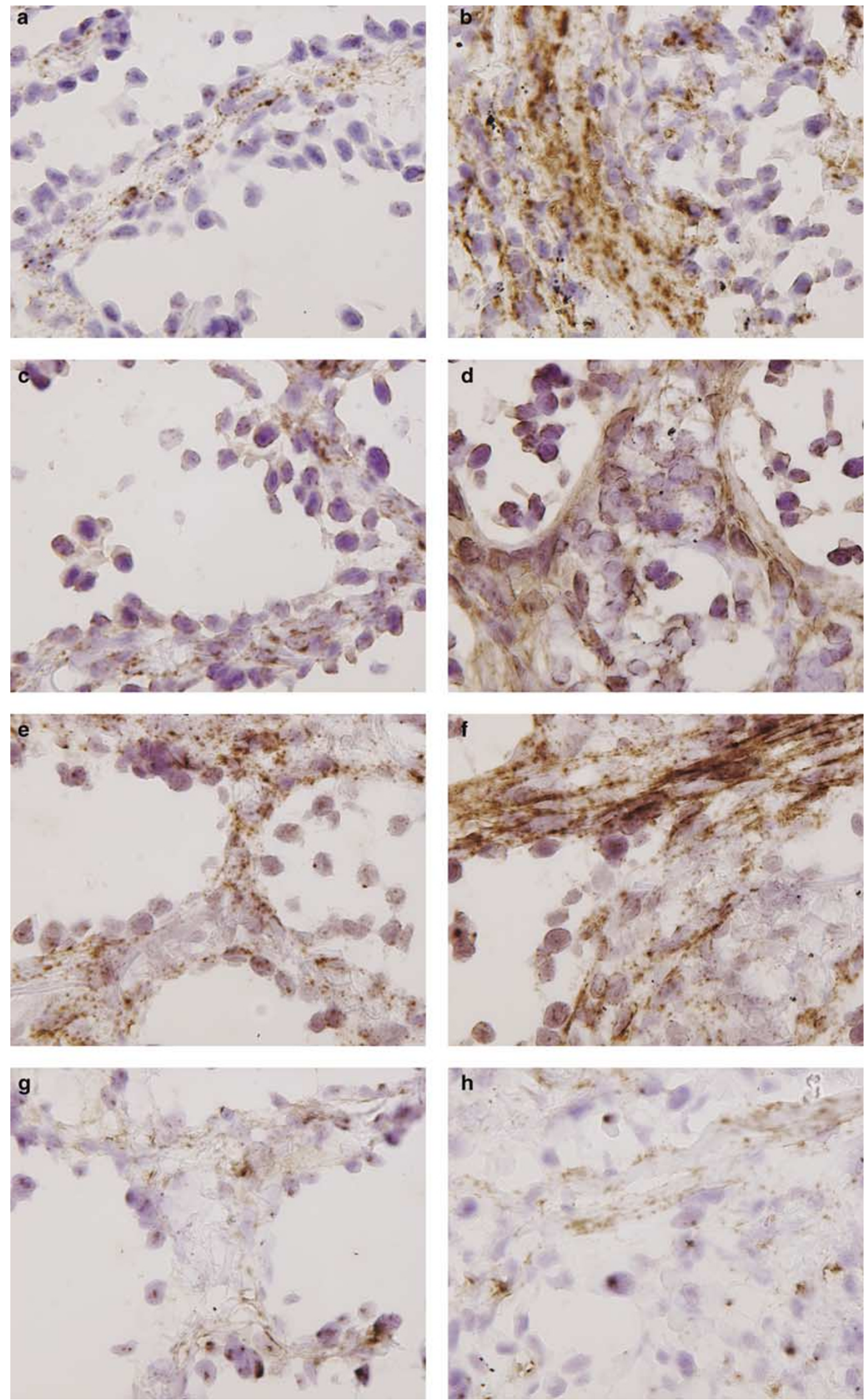
Table 4 Results of in situ hybridization: (a) Total mRNA expression in epithelial cells and stromal fibroblast-type cells, (b) mRNA expression in epithelial cells and (c) mRNA expression in stromal fibroblast-type cells

\begin{tabular}{|c|c|c|c|}
\hline & Normal & $\begin{array}{l}\text { Noninvasive } \\
\text { carcinoma }\end{array}$ & $\begin{array}{l}\text { Invasive } \\
\text { carcinoma }\end{array}$ \\
\hline \multicolumn{4}{|c|}{$\begin{array}{l}\text { (a) Total mRNA expression in epithelial cells and stromal } \\
\text { fibroblast-type cells }\end{array}$} \\
\hline MMP2 & & $P=0.0078^{*} \quad P=0.2646$ & $\begin{array}{l}3.86 \pm 0.86 \\
46\end{array}$ \\
\hline MMP9 & \multicolumn{3}{|c|}{$\begin{array}{c}P=0.0190^{*} \quad P=0.5803 \\
P<0.0001^{*}\end{array}$} \\
\hline \multirow[t]{2}{*}{ MT1MMP } & $2.64 \pm 1.59$ & $\begin{array}{c}P<0.0001^{*} \\
4.14 \pm 1.29\end{array}$ & $4.71 \pm 0.99$ \\
\hline & \multicolumn{3}{|c|}{$P=0.0170^{*} \quad P=0.5238$} \\
\hline \multirow[t]{2}{*}{ TIMP2 } & $1.07 \pm 0.92$ & $1.93 \pm 0.83$ & $2.36 \pm 0.75$ \\
\hline & \multicolumn{3}{|c|}{$\begin{array}{c}P=0.0337^{*} \quad P=0.4046 \\
P=0.0100^{*}\end{array}$} \\
\hline
\end{tabular}

(b) mRNA expression in epithelial cells

\begin{tabular}{|c|c|c|c|}
\hline MMP2 & $0.71 \pm 0.61$ & $1.14 \pm 0.66$ & $1.36 \pm c$ \\
\hline & & $57 \quad P=$ & \\
\hline & & $P=0.0244^{*}$ & \\
\hline MMP9 & $0.93 \pm 0.62$ & $1.71 \pm 0.73$ & $1.86 \pm 0.66$ \\
\hline & & $35^{*} \quad P=$ & 34 \\
\hline & & $P=0.0031^{*}$ & \\
\hline MT1MMP & $0.14 \pm 0.86$ & $2.07 \pm 0.62$ & $2.36 \pm 0.63$ \\
\hline & & 57* $\quad P=$ & 751 \\
\hline & & $P=0.0003^{*}$ & \\
\hline TIMP2 & $0.29 \pm 0.47$ & $0.86 \pm 0.54$ & $0.86 \pm 0.54$ \\
\hline & & $200^{*}$ & \\
\hline & & $P=0.0200^{*}$ & \\
\hline c) $m R N$ & ssion in stro & broblast-type & \\
\hline MMP2 & $1.43 \pm 0.76$ & $2.07 \pm 0.48$ & $2.50 \pm 0.52$ \\
\hline & & $48^{*}-\mathrm{P}=$ & $72-$ \\
\hline & & $P=0.0001^{*}$ & \\
\hline MMP9 & $1.07 \pm 0.62$ & $1.86 \pm 0.66$ & $2.14 \pm 0.54$ \\
\hline & & $59^{*} \quad P=$ & 72 \\
\hline & & $P=0.0002^{*}$ & \\
\hline MT1MMP & $1.50 \pm 0.86$ & $2.07 \pm 0.83$ & $2.36 \pm 0.75$ \\
\hline & & $93 \quad P=$ & \\
\hline & & $P=0.0283^{*}$ & \\
\hline TIMP2 & $0.79 \pm 0.58$ & $1.07 \pm 0.48$ & $1.50 \pm 0.52$ \\
\hline & & $54-P=$ & \\
\hline & & $P=0.0380^{*}$ & \\
\hline
\end{tabular}

Mean \pm s.d., ${ }^{*} P<0.05$.

\section{Discussion}

Transcripts for MMP2, MMP9, MT1-MMP, and TIMP2 were clearly evident in both bronchioloalveolar carcinoma and invasive carcinomas. This is the first report to show that MMP mRNAs are predominantly expressed in the stromal cells of lung cancers. We confirmed the concomitant gelatinolytic activity of these MMPs by conventional and in situ zymography.

There have been only three reports of MMPs in bronchioloalveolar carcinomas, as far as we know. ${ }^{19-21}$ Earlier studies have reported lower frequencies of MMP2 expression in bronchioloalveolar carcinomas. Kodate et $a l^{19}$ showed that two of 11 cases $(18 \%)$ of bronchioloalveolar carcinoma
Table 5 Results of in situ hybridization. Comparison of MMP mRNA in epithelial cells and stromal fibroblast-type cells

\begin{tabular}{|c|c|c|c|c|}
\hline & \multicolumn{2}{|c|}{$\begin{array}{l}\text { Noninvasive carcinoma } \\
\text { area }\end{array}$} & \multicolumn{2}{|c|}{$\begin{array}{c}\text { Invasive carcinoma } \\
\text { area }\end{array}$} \\
\hline & $\begin{array}{l}\text { Epithelial } \\
\quad \text { cells }\end{array}$ & $\begin{array}{l}\text { Stromal } \\
\text { fibroblast- } \\
\text { type cells }\end{array}$ & $\begin{array}{l}\text { Epithelial } \\
\text { cells }\end{array}$ & $\begin{array}{c}\text { Stromal } \\
\text { fibroblast- } \\
\text { type cells }\end{array}$ \\
\hline MMP2 & \multicolumn{2}{|c|}{$P=0.0003^{*}$} & \multicolumn{2}{|c|}{$P<0.0001^{*}$} \\
\hline MMP9 & \multicolumn{2}{|c|}{$P=0.5914$} & \multicolumn{2}{|c|}{$P=0.2205$} \\
\hline MT1MMP & \multicolumn{2}{|c|}{$P=0.7908$} & \multicolumn{2}{|c|}{-} \\
\hline TIMP2 & $\begin{array}{r}0.86 \pm 0.54 \\
P=\end{array}$ & $\begin{array}{l}1.07 \pm 0.48 \\
2723\end{array}$ & $\begin{array}{r}0.93 \pm 0.73 \\
P=0\end{array}$ & $\begin{array}{l}1.50 \pm 0.52 \\
0245^{*}\end{array}$ \\
\hline
\end{tabular}

Mean \pm s.d., ${ }^{*} P<0.05$

expressed MMP2, and that one of 11 cases expressed MMP9. Kitamura et $a l^{20}$ reported eight of 48 cases $(17 \%)$ of lung adenocarcinoma expressed MMP2 in the lepidic growth areas. However, Kumaki et $a 2^{21}$ detected the expression of MMP2 immunohistochemically in 26 of 27 of bronchioloalveolar carcinomas (96\%). This discrepancy might be the result of different immunodetection methods used or other technical factors. MMP is a secreted protein, except for membrane-type MMPs such as MT1-MMP. During fixation, processing, or staining, the target protein can be lost. We used in situ hybridization to avoid this problem and to determine the actual site of MMP synthesis. Transcripts for MMP2, MMP9, MT1-MMP, and TIMP2 were detected both in bronchioloalveolar carcinomas and in the invasive component of adenocarcinomas in 14 of 14 cases $(100 \%)$. Signal intensity increased gradually with tumor progression.

By histological definition, bronchioloalveolar carcinoma of the lung has no invasive focus. ${ }^{22}$ We anticipated that a bronchioloalveolar carcinoma would have little MMP mRNA and minimal gelatinolytic activity, as reported in earlier immunohistochemical studies. ${ }^{19,20}$ Surprisingly, in situ hybridization showed that bronchioloalveolar carcinomas had significant amounts of mRNA for MMP2, MMP9, MT1-MMP, and TIMP2. In four cases of bronchioloalveolar carcinoma, the gelatinolytic activity was sufficient to destroy the basement membrane. Our observations are consistent with previous studies in which the basement membrane of the bronchioloalveolar carcinoma was often destroyed. ${ }^{21,24,26}$ Our results suggest that noninvasive carcinoma components in mixed adenocarcinoma already express a molecular mechanism involving MMPs similar to that expressed in invasive carcinomas. Destruction of the basement membrane was observed in bronchioloalveolar 
Table 6 Correlation between basement membrane status and in situ hybridization results in non-invasive carcinoma area

\begin{tabular}{|c|c|c|c|c|}
\hline & Epithelial cells & Stromal fibroblast-type cells & Epithelial cells & Stromal fibroblast-type cells \\
\hline MMP2 & & & MMP9 & \\
\hline $\mathrm{CP}$ & $1.00 \pm 0.67$ & $1.90 \pm 0.32$ & $1.60 \pm 0.70$ & $1.60 \pm 0.52$ \\
\hline PD & $1.50 \pm 0.58, P=0.203$ & $2.50 \pm 0.58, P=0.030^{*}$ & $2.00 \pm 0.82, P=0.407$ & $2.50 \pm 0.33, P=0.026^{*}$ \\
\hline MT1MMP & & & TIMP2 & \\
\hline $\mathrm{CP}$ & $2.10 \pm 0.57$ & $2.00 \pm 0.94$ & $0.08 \pm 0.42$ & $1.10 \pm 0.32$ \\
\hline $\mathrm{PD}$ & $2.00 \pm 0.82, P=0.803$ & $2.25 \pm 0.50, P=0.653$ & $1.00 \pm 0.82, P=0.593$ & $1.00 \pm 0.82, P=0.767$ \\
\hline
\end{tabular}

CP, complete preservation; PD, partial destruction; mean \pm s.d., ${ }^{*} P<0.05$.

Table 7 The activation rate of MMP2 and in situ zymography results

\begin{tabular}{|c|c|c|c|c|c|c|}
\hline \multirow[t]{2}{*}{ Case } & \multicolumn{3}{|c|}{$\begin{array}{l}\text { MMP2 activation rate } \\
\text { measured by zymography }\end{array}$} & \multicolumn{3}{|c|}{$\begin{array}{l}\text { Film in situ } \\
\text { zymography }\end{array}$} \\
\hline & $N(\%)$ & $T(\%)$ & $T / N$ & $N$ & NIN & $I N V$ \\
\hline 1 & 30.6 & 45.9 & 1.6 & \pm & + & + \\
\hline 2 & 17.6 & 29.8 & 1.69 & - & \pm & + \\
\hline 3 & 49 & 78.3 & 1.6 & \pm & + & + \\
\hline 4 & 30 & 77.1 & 2.57 & - & + & + \\
\hline 5 & 43.3 & 54.2 & 1.25 & - & + & + \\
\hline 6 & 33.4 & 33.7 & 1.01 & - & \pm & + \\
\hline 7 & 31.5 & 38.5 & 1.22 & \pm & + & + \\
\hline 8 & 34.7 & 64.9 & 1.87 & - & + & + \\
\hline 9 & 25.5 & 61.9 & 2.43 & - & + & + \\
\hline 10 & 27.1 & 57.3 & 2.11 & - & + & + \\
\hline 11 & 25 & 47.9 & 1.92 & \pm & + & + \\
\hline 12 & 55.7 & 46.4 & 0.83 & \pm & + & + \\
\hline 13 & 28.8 & 61.1 & 2.12 & - & + & + \\
\hline 14 & 34.5 & 60.4 & 1.75 & \pm & + & + \\
\hline
\end{tabular}

$\mathrm{N}$, tumor-free tissue; T, tumor tissue; NIN, noninvasive carcinoma area; INV, invasive carcinoma area.

carcinomas with myofibroblastic proliferation. In situ hybridization showed that the main source of MMPs was the stromal fibroblast-type cells. The elevated transcripts of MMP2 and MMP9 in the stromal fibroblast-type cells were correlated with the basement membrane destruction. These observations suggest that MMP-secreting stromal cells are crucial for tumor invasion.

The stromal fibroblast-type cell is not an actual part of the neoplasm. Ishii et $a l^{27}$ showed that cancer-induced myofibroblasts are derived from the bone marrow. MMP produced by the stromal fibroblast-type cells is, of course, not directly produced by the cancer cells, but the MMP from the stromal fibroblast-type cell is likely to be associated with cancer invasion. Classically, the stromal fibroblast-type cells surrounding carcinoma cells have been thought to result from the defensive reaction of the host. However, increasing evidences suggests that stromal fibroblast-type cell can assist tumor progression in the microenvironment of the cancer and stroma. ${ }^{2}$

Some bronchioloalveolar carcinomas with disrupted basement membranes could be fully ready for invasion. In such cases, a tumor motility
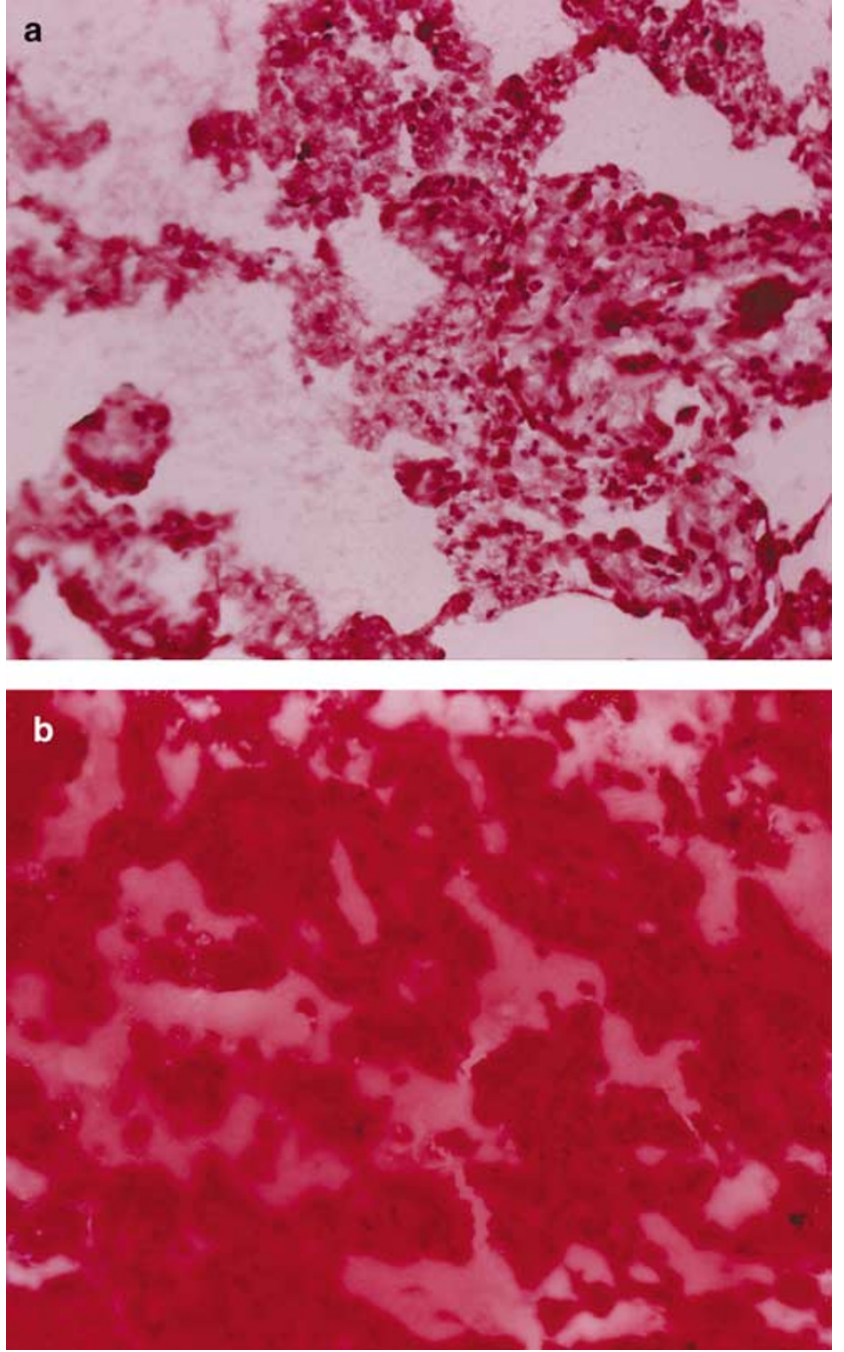

Figure 3 Film in situ zymography. A bronchioloalveolar carcinoma showing gelatinolytic activity (a). Gelatinolytic activity was suppressed by 1,10-phenanthroline (b).

mechanism, such as the HGF/c-MET system, would be important. Tokunou et $a 1^{28}$ reported that c-Met immunoreactivity was observed mainly in the invasive areas of lung adenocarcinomas, whereas only a small proportion of cells in bronchioloalveolar carcinomas expressed c-Met.

We have shown that stromal fibroblast-type cells were the main source of MMP2 and TIMP2 at each 
stage of lung adenocarcinoma. Early in 1980, Shimosato et $a l^{29}$ reported that fibrotic foci were negative prognostic factor in small peripheral lung adenocarcinomas. Recently, fibrotic foci were reported to be an important factor in the stromal-invasion grading of lung adenocarcinoma. ${ }^{30,31}$ Noguchi et $a l^{32}$ reported that the presence of active fibroblast proliferation correlated with a poor prognosis in small lung adenocarcinoma. We here present strong evidence that fibroblast-type cells are important for the motility of lung adenocarcinomas.

The extracellular matrix metalloproteinase inducer (EMMPRIN; CD147) is expressed in both tumor epithelial cells and peritumor stromal cells. ${ }^{33}$ It is interesting that an inducer is itself secreted by stromal cells. These studies underscore the important role of stromal cells in cancer progression. MT1MMP mRNA is predominantly expressed in stromal fibroblast-type cells in tumor-free tissue. However, in both bronchioloalveolar carcinoma and invasive carcinoma areas, epithelial cells (carcinoma cells) and stromal cells exhibited equal levels of MT1MMP mRNA. MT1-MMP, an activator of MMP2, is a transmembrane protein. Therefore, the MT1-MMP synthesized by carcinoma cells might be more important in actual tumor invasion than the MT1MMP synthesized by stromal cells.

The present study did not include pure bronchioloalveolar carcinoma. Pure bronchioloalveolar carcinoma may have different molecular mechanisms involving MMP from those of noninvasive carcinoma component of mixed adenocarcinoma, despite their identical morphologies. Several inflammatory lung diseases are known to produce MMP. ${ }^{34-38}$ Some sort of reactive process may involve MMP expression in surrounding carcinomas. Further study of MMP, including its expression in pure bronchioloalveolar carcinoma and inflammatory lung diseases, would therefore be valuable.

Taken together, our data on lung mixed adenocarcinomas indicate that bronchioloalveolar carcinomas express mRNAs for MMP2, MMP9, MT1-MMP, and TIMP2 and the corresponding gelatinolytic activities. A further combination study of MMP and the tumor motility system should extend our understanding of the invasion of lung adenocarcinomas. MMP2, MMP9, and TIMP2 mRNAs are invariably expressed predominantly in stromal fibroblast-type cells in tumor-free and carcinoma tissues. Stromal fibroblast-type cells are crucial for carcinoma invasion. The investigation of stromatargeted cancer therapy is therefore warranted.

\section{Acknowledgements}

We thank Ryoichi Nemori for providing gelatin films, Chie Okumura and Yoko Okuhara for their excellent technical assistance, and Motoko Suzaki for her valuable secretarial support. This work was supported in part by a Grant-in-Aid for Cancer
Research from the Ministry of Health, Labour of Japan and Welfare and by a Grant-in-Aid for the Second-Term Comprehensive 10-Year Strategy for Cancer Control from the Ministry of Health, Labour and Welfare of Japan. NK is a recipient of Research Resident Fellowships from the Foundation for the Promotion of Cancer Research, Tokyo.

\section{References}

1 Chambers AF, Matrisian LM. Changing views of the role of matrix metalloproteinases in metastasis. J Natl Cancer Inst 1997;89:1260-1270.

2 Liotta LA, Kohn EC. The microenvironment of the tumour-host interface. Nature 2001;411:375-379.

3 Nakahara H, Howard L, Thompson EW, et al. Transmembrane/cytoplasmic domain-mediated membrane type 1-matrix metalloprotease docking to invadopodia is required for cell invasion. Proc Natl Acad Sci USA 1997;94:7959-7964.

4 Urbanski SJ, Edwards DR, Maitland A, et al. Expression of metalloproteinases and their inhibitors in primary pulmonary carcinomas. Br J Cancer 1992;66: 1188-1194.

5 Brown PD, Bloxidge RE, Stuart NS, et al. Association between expression of activated 72-kilodalton gelatinase and tumor spread in non-small-cell lung carcinoma. J Natl Cancer Inst 1993;85:574-578.

6 Soini Y, Paakko P, Autio-Harmainen H. Genes of laminin B1 chain, alpha 1 (IV) chain of type IV collagen, and 72-kd type IV collagenase are mainly expressed by the stromal cells of lung carcinomas. Am J Pathol 1993;142:1622-1630.

7 Anderson IC, Sugarbaker DJ, Ganju RK, et al. Stromelysin-3 is overexpressed by stromal elements in primary non-small cell lung cancers and regulated by retinoic acid in pulmonary fibroblasts. Cancer Res 1995;55:4120-4126.

8 Tokuraku M, Sato H, Murakami S, et al. Activation of the precursor of gelatinase A/72 kDa type IV collagenase/MMP-2 in lung carcinomas correlates with the expression of membrane-type matrix metalloproteinase (MT-MMP) and with lymph node metastasis. Int J Cancer 1995;64:355-359.

9 Polette M, Nawrocki B, Gilles C, et al. MT-MMP expression and localisation in human lung and breast cancers. Virchows Arch 1996;428:29-35.

10 Bolon I, Brambilla E, Vandenbunder B, et al. Changes in the expression of matrix proteases and of the transcription factor c-Ets-1 during progression of precancerous bronchial lesions. Lab Invest 1996; 75:1-13.

11 Kawano N, Osawa $\mathrm{H}$, Ito $\mathrm{T}$, et al. Expression of gelatinase A, tissue inhibitor of metalloproteinases-2, matrilysin, and trypsin(ogen) in lung neoplasms: an immunohistochemical study. Hum Pathol 1997;28: 613-622.

12 Nawrocki B, Polette M, Marchand V, et al. Expression of matrix metalloproteinases and their inhibitors in human bronchopulmonary carcinomas: quantificative and morphological analyses. Int J Cancer 1997;72: 556-564.

13 Suzuki M, Iizasa T, Fujisawa T, et al. Expression of matrix metalloproteinases and tissue inhibitor of 
matrix metalloproteinases in non-small-cell lung cancer. Invas Metast 1998;18:134-141.

14 Martinella-Catusse C, Nawrocki B, Gilles C, et al. Matrix-metalloproteinases in bronchopulmonary carcinomas. Histol Histopathol 1999;14:839-843.

15 Michael M, Babic B, Khokha R, et al. Expression and prognostic significance of metalloproteinases and their tissue inhibitors in patients with small-cell lung cancer. J Clin Oncol 1999;17:1802-1808.

16 Cox G, Jones JL, O’Byrne KJ. Matrix metalloproteinase 9 and the epidermal growth factor signal pathway in operable non-small cell lung cancer. Clin Cancer Res 2000;6:2349-2355.

17 Herbst RS, Yano S, Kuniyasu H, et al. Differential expression of E-cadherin and type IV collagenase genes predicts outcome in patients with stage I nonsmall cell lung carcinoma. Clin Cancer Res 2000;6: 790-797.

18 Thomas P, Khokha R, Shepherd FA, et al. Differential expression of matrix metalloproteinases and their inhibitors in non-small cell lung cancer. J Pathol 2000; 190:150-156.

19 Kodate M, Kasai T, Hashimoto H, et al. Expression of matrix metalloproteinase (gelatinase) in T1 adenocarcinoma of the lung. Pathol Int 1997;47:461-469.

20 Kitamura H, Oosawa Y, Kawano N, et al. Basement membrane patterns, gelatinase $\mathrm{A}$ and tissue inhibitor of metalloproteinase-2 expressions, and stromal fibrosis during the development of peripheral lung adenocarcinoma. Hum Pathol 1999;30:331-338.

21 Kumaki F, Matsui K, Kawai T, et al. Expression of matrix metalloproteinases in invasive pulmonary adenocarcinoma with bronchioloalveolar component and atypical adenomatous hyperplasia. Am J Pathol 2001;159:2125-2135.

22 Travis W, Colby T, Corrin B, et al. Histological Typing of Lung and Pleural Tumours. World Health Organization International Histological Classification of Tumours, 3rd edn. Springer: Berlin, 1999.

23 Sobin L, Wittekind C. UICC, TNM Classification of Malignant Tumours, 5th edn. John Wiley \& Sons: New York, NY, 1997.

24 Goto K, Yokose T, Kodama T, et al. Detection of early invasion on the basis of basement membrane destruction in small adenocarcinomas of the lung and its clinical implications. Mod Pathol 2001;14:1237-1245.

25 Ohashi K, Nemoto T, Nakamura K, et al. Increased expression of matrix metalloproteinase 7 and 9 and membrane type 1-matrix metalloproteinase in esophageal squamous cell carcinomas. Cancer 2000;88: 2201-2209.
26 Ohori NP, Yousem SA, Griffin J, et al. Comparison of extracellular matrix antigens in subtypes of bronchioloalveolar carcinoma and conventional pulmonary adenocarcinoma. An immunohistochemical study. Am J Surg Pathol 1992;16:675-686.

27 Ishii G, Sangai T, Oda T, et al. Bone-marrow-derived myofibroblasts contribute to the cancer-induced stromal reaction. Biochem Biophys Res Commun 2003; 309:232-240.

28 Tokunou M, Niki T, Eguchi K, et al. c-MET expression in myofibroblasts: role in autocrine activation and prognostic significance in lung adenocarcinoma. Am J Pathol 2001;158:1451-1463.

29 Shimosato Y, Suzuki A, Hashimoto T, et al. Prognostic implications of fibrotic focus (scar) in small peripheral lung cancers. Am J Surg Pathol 1980;4:365-373.

30 Maeshima AM, Niki T, Maeshima A, et al. Modified scar grade: a prognostic indicator in small peripheral lung adenocarcinoma. Cancer 2002;95:2546-2554.

31 Sakurai H, Maeshima A, Watanabe S, et al. Grade of stromal invasion in small adenocarcinoma of the lung: histopathological minimal invasion and prognosis. Am J Surg Pathol 2004;28:198-206.

32 Noguchi M, Morikawa A, Kawasaki M, et al. Small adenocarcinoma of the lung. Histologic characteristics and prognosis. Cancer 1995;75:2844-2852.

33 Caudroy S, Polette M, Tournier JM, et al. Expression of the extracellular matrix metalloproteinase inducer (EMMPRIN) and the matrix metalloproteinase-2 in bronchopulmonary and breast lesions. J Histochem Cytochem 1999;47:1575-1580.

34 Dahlen B, Shute J, Howarth P. Immunohistochemical localisation of the matrix metalloproteinases MMP-3 and MMP-9 within the airways in asthma. Thorax 1999;54:590-596.

35 Segura-Valdez L, Pardo A, Gaxiola M, et al. Upregulation of gelatinases A and B, collagenases 1 and 2, and increased parenchymal cell death in COPD. Chest 2000;117:684-694.

36 Suga M, Iyonaga K, Okamoto $\mathrm{T}$, et al. Characteristic elevation of matrix metalloproteinase activity in idiopathic interstitial pneumonias. Am J Respir Crit Care Med 2000;162:1949-1956.

37 Maisi P, Prikk K, Sepper R, et al. Soluble membranetype 1 matrix metalloproteinase (MT1-MMP) and gelatinase A (MMP-2) in induced sputum and bronchoalveolar lavage fluid of human bronchial asthma and bronchiectasis. APMIS 2002;110:771-782.

38 Han Z, Junxu, Zhong N. Expression of matrix metalloproteinases MMP-9 within the airways in asthma. Respir Med 2003;97:563-567. 